CSABA CSISZÁR, Ph.D. ${ }^{1}$

E-mail: csiszar.csaba@mail.bme.hu

DÁVID FöLDES, Ph.D. student ${ }^{1}$

(Corresponding author)

E-mail: foldes.david@mail.bme.hu

${ }^{1}$ Budapest University of Technology and Economics (BME),

Faculty of Transportation Engineering and Vehicle

Engineering (KJK), Department of Transport Technology

and Economics (KUKG) Múegyetem rkp.3.,

H-1111 Budapest, Hungary
Traffic Management

Preliminary Communication

Submitted: 16 May 2017

Accepted: 28 Nov. 2017

\title{
SYSTEM MODEL FOR AUTONOMOUS ROAD FREIGHT TRANSPORTATION
}

\begin{abstract}
Emerging info-communication and vehicle technologies (especially vehicle automation) facilitate evolvement of autonomous road freight transportation. The entire transport system and its operation undergo a major change. New service concepts are growing and the existing ones are being transformed. The changing is particularly significant in city logistics. However, there are debates about the ways of automation of processes targeting improvement of capacity utilisation and decrease of expenditures. The main research questions of the paper are therefore: what properties of the future autonomous freight transportation are presumed; what system structure is to be constructed and how the system is to be operated? After introducing the basic notions and reviews of the current systems and developments, the shifting from traditional freight transportation to autonomous system is investigated by several aspects. A system- and process-oriented analytical modelling method has been applied. The main system constituents and their connections are modelled. Finally, we elaborate the operational model of road freight transportation, which is applicable principally in metropolitan areas. In conclusion, the presented results appoint the research and innovation trends towards the automation of freight transportation.
\end{abstract}

\section{KEY WORDS}

autonomous freight vehicle; system structure; operational model; city logistics;

\section{INTRODUCTION}

The technological development in the field of autonomous road vehicles (AV) is large-scale. Innovations of personal car industry have been coming up with impressive developments. Nevertheless, a more straightforward advent of driverless systems might be envisaged in freight transportation, where automatized storage and loading systems are connected to transportation.

There are already some thought-provoking, interesting practical applications. For example, very large automated trucks with a maximum load capacity of
290 metric tons have been used at one of the world's largest iron-ore mines in Australia since the 1990s [1]. Automated vehicles have been used in port container terminals for years. These applications are mainly operated in demarcated and access-restricted areas [2].

Automated and autonomous freight transport will expectedly consist of high-capacity (e.g. trucks) and small capacity (e.g. vans) vehicles. The small capacity vehicles will be mainly applied in urban environment. It is clearly seen that in the next decades a significant number of the new vehicles will be increasingly autonomous which represents a quite short-term technological shift. Considering the average planning, procurement times and average vehicle 'lifetime', the transformation and its predictable impacts are worth a discussion. The question is no longer 'if' but 'when' these vehicles will appear in freight transportation. The logistics industry can adopt self-driving vehicles much faster than most other industries. The reason for this is that different rules apply when a vehicle is moving around in a secure, private zone (e.g. yards of a manufactory). Also, liability issues are less pressing when that vehicle is transporting goods instead of people.

The efficient logistics systems are already well-organized and managed; however, the autonomous transport requires new planning and control methods, as well as automatized procedures considering the high complexity of supply chains. Accordingly, the paper intends to reveal the opportunities of autonomous technology applying in the field of freight transportation. Not only the transportation but also the entire logistics system as a framework is considered.

The main research questions are:

1) How is the autonomous freight transportation system to be defined and modelled?

2) How is the operation to be modelled? What operational challenges are to be tackled?

3) What modifications are required in the organisational structure? 
The entire automation requires long time and several levels can be distinguished. During the research, we considered only the highest level where the driver is entirely replaced by a machine.

The novelty of this work lies in the fact that studies deal primarily with the development of vehicle technology and modelling the impacts of private cars on road usage, while management of road freight transportation requires a more complex approach; especially, when the entire supply chain is considered. The results of this paper fill this niche; namely, the technological advancement is placed into a wider context in order to reveal relevant issues and correspondences which are to be tackled in the future. The theoretical (conceptual) framework has been elaborated. To our knowledge, no other scholar work summarizes the transformation of conventional road freight transportation in a similar, system and process oriented approach.

The remainder of the paper is structured as follows. Basic notions are introduced and summarized in Section 2. Then, we analyse the current situation. The automated road freight transportation is inserted into the computer-integrated transportation concept. In Section 3, we elaborate the structural model and present the dynamic character of the system. In Section 4, the operational model is summarized, focusing on control and management functions of the organisations. The paper is completed by the concluding remarks including the potential future research directions.

\section{STATE OF THE ART}

In order to summarize the state of the art firstly, the basic notions were clarified. Then, the literature was reviewed to meet the existing systems and experiences. Finally, we created the model of computer integrated logistics (CIL) where automated operations are performed by autonomous vehicles and devices.

\subsection{Definition of basic notions}

The general definition of a system according to [3]: the system is a set of interacting or interdependent components forming a complex whole. Every system is delineated by its spatial and temporal boundaries, surrounded and influenced by its environment, described by its structure and purpose and expressed in its functioning. The system is a relative notion. In this paper, the autonomous road freight transportation as an intelligent system is modelled.

A subsystem is a relatively separated and identifiable part (component, element) of a system. The AV is an intelligent subsystem of road freight transportation system.
The model can be considered as abstractions of objective reality. The system model is a simplified abstraction of the real system highlighting only the relevant attributes in the given research and development.

Several types of automated vehicles are already in operation. However, the concept of AVs has emerged only recently. Accordingly, an exact terminology should be introduced. Differences between automated and AVs are as follows.

Automated vehicles are controlled by computers following exactly the described, step-by-step rules which were programmed into them. All the potential situations and their consequences are programmed in advance. These vehicles are running on separated paths.

Autonomous vehicles are controlled by computers with artificial intelligence which is able to manage unknown situations making individual decisions using cognitive capabilities and learning capacities. They are able to run on not-separated paths, too. The vehicles are mainly powered by either battery or fuel-cell electricity. Self-driving vehicles can be defined as the vehicles which do not require any 'direct driver input, to control the steering, acceleration, and braking' of the vehicle, and do not require the driver to "constantly monitor the roadway while operating in self-driving mode' [4].

Alteration of transport technology implies application of smart cargo. The smart cargo has a unique identity; it is capable of communication with its environment, it stores data, it has a language to display its features, and it participates directly in or makes decisions relevant to its own routing [5].

AVs and intelligent cargo may be applied in autonomous logistics systems. Autonomous logistics systems are managed, shaped and developed by themselves. They are operationally closed, which means that the decisions, relationships, and interactions are not dependent on external controls.

As there is no fully closed operating system, autonomy is always to be interpreted as a relative concept [6]. Accordingly, logistics systems and AVs have external information connections. With consideration of enterprise boundaries two types of logistics systems are distinguished:

1) Extra-logistics: transport and stock management (material and information flows) between enterprises.

2) Intra-logistics: material handling and stock management within enterprises.

The freight transportation system is one of the most relevant subsystems of smart cities. Smart city concepts aim to create a liveable and energy-efficient city using advanced technology. Smart grid solutions facilitate efficient energy management. However, the electric network and especially the batteries of the vehicle should be significantly improved. 
The available large amount of data and information technology indicates new concepts and framework. Industry 4.0 is an expression which describes the current trend of automation in manufacturing. Internet of Things (IOT) is a framework where the objects are able to collect and exchange data. Lom et al. [7] has proposed to unite the view of the concept of Industry 4.0 and the Smart City Initiative. They found that both building smart city or a fully automated company process according to Industry 4.0, most attention must be paid to sharing (not only vehicles but even infrastructure), minimisation of resources or storage, orientation on services and accessibility rather than mobility and integration.

\subsection{Literature review}

The four- or five-level definition for autonomous technology focusing only on vehicle control is already well-known in the automotive world. National Highway Traffic Safety Administration [4] provided guidance to states permitting tests for driverless vehicle technology. SAE (Society of Automotive Engineers) determined exact terminology and taxonomy for AVs in a standard [8]. BASt (Bundesanstalt für Straßenwesen), the German Federal Highway Research Institute made similar definitions [9]. Furthermore, five Grades of Automation (GoA) was introduced by International Association of Public Transport which is a bit more complex categorisation considering management and control function [10].

According to SAE levels, the currently used vehicles meet only Level 1 or 2 requirements; most of the functions are controlled by human driver, the machine provides driver assistance or partial automation. In order to reach full automation several technological, ethical and legal issues should be solved. For instance, nobody takes responsibility for the operation of a program created by machine in our days. Currently, the autonomous vehicles are only in test phase with human supervisor. According to the commonly used law, a human 'driver' should be in the car during any movement.

Flaming [1] examined the issues of fully automated vehicles use on freight transport and determined relevant potential areas. It was found that from a microeconomic perspective, a lack of driving personnel, an energy-saving driving style, high reliability and accident evasion are significant reasons to employ autonomous systems in the freight transport chain. If the driver no longer 'accompanies' the vehicle, their activities (e.g. loading and unloading) would have to be performed by others. Companies should hire or train their own staff for such activities. The logistics companies might also opt for a different business model to account for these changes. This could lead to a general revolution of work and the creation of local jobs, particularly in urban areas.

Public acceptance of fully automated systems is limited; not least due to continuous reports of failures of mechanical or electronic components in vehicles, or the fear of unstable data connections. The step-bystep implementation, for instance, of platooning, starting with manned lead and following vehicles, could build the requisite acceptance among the public [1].

Automated systems (robots) have been already used in production and assembly processes, incoming and outgoing goods areas as well as picking areas and warehouses. The indoor AGT (Automated Guided Transport) system relies on laser scanners, and RFID technology for picking up the goods. Navigation relies on a magnetic point sequence guide system, or indoor GPS system, and the control system utilizes wireless-technology for data transmission. At a container terminal, automated guided vehicles move containers between the container cranes and the stacking area. The objective is to shorten routes, reduce empty trips and achieve optimal utilisation of all resources. Corman et al. [11] provided a new optimisation model and algorithm for scheduling and routing automated container moving equipment. The introduced model maximizes the operational efficiency assigning the best automated vehicle and operation time to a set of containers.

Possible adaptation of autonomous systems in logistics are:

- autonomous loading and transport in a warehouse,

- outdoor logistics operation in yards - container and unit load devices,

- line haul transportation - convoying (=platooning),

- last-mile delivery.

The last mile of delivery is often the least predictable part of the entire process because of the complex and dynamic feature of cities. Delivery personnel cope with rapidly increasing parcel volumes caused by the growing popularity of e-commerce. Some possible future solutions using AVs are [12]:

- just-in-time refilling shops from remote warehouses,

- self-driving pick-pack points, which could autonomously come (closer) to the customers,

- autonomous shared shopping cars (ordering things via internet, the purchased goods are loaded into the trunk and the AV drives to the destination),

- self-driving parcels as small 'cars',

- waste collection.

Organizing and management issues of autonomous freight transportation were investigated in several papers. Sternberg and Andersson [13] provided an outlook on the concept of decentralized freight intelligence. They found that critical mass of decentralized freight vehicles must be achieved to utilize the benefits e.g. reduced administration, reduced driven 
kilometres, etc. Arendt et al. [14] introduced a multiagent-based approach that enables an autonomous dispatch process in a realistic transport scenario. The autonomous coordination of transport services and planning processes can help to cope with the dynamics and distributed nature of logistics networks (e.g. the growing variety of special equipment and vehicle types). Simulation experiments showed that the procedure leads to a reduction of empty mileage and increases capacity utilisation of vehicles.

The general impact of autonomous transportation to the traffic has been examined in several papers. The coupling of vehicles (platooning) would enable to improve utilisation of the road infrastructure, and to reduce fuel consumption and emissions due to reduced wind resistance. The platooning vehicles would be connected via V2V (Vehicle to Vehicle) communication system [15]. Significant weaknesses of the truck platooning could be the responsibility and liability issues in the case of accidents. Another unsolved issue, to which extent such platooning on the right lane can hinder a private car which wants to take an off-ramp or drives on an on-ramp [16].

The so called transitional period seems to be quite long, when vehicles with different automation level run in heterogeneous traffic with the 'conventional' vehicles. In the transitional period, cooperation requires special methods and driver skills. A mixture of automated and manual elements in logistic chains implies new challenges, especially during the 'transitional' period. New optimisation algorithms that are able to deal with heterogeneous traffic and new traffic management policies for traffic management centres are needed as more accurate traffic state estimations are available [17]. Communication between AVs, automated equipment and human participants (e.g. loading staff, customers, drivers of conventional vehicles) requires novel human-machine interfaces and information management procedures. On one hand, intentions and messages of machines should be understandable and clear. On the other hand, significant alteration is required in human behaviour and information management (e.g. human and machine elements should identify each other). Fewer employees are needed, but other skills and higher educational background is required from them, as a consequence of automation.

Different scenarios should be introduced in order to model the transitional period when the traffic is heterogeneous. Existing studies consider mostly the proportion of different type of passenger transportation modes based on AVs [18, 19]. Bansal and Kockelman [20] stated that rise in most people's willingness to pay and acceptance towards AVs, promotion of AVs and unusually rapid reductions in technology costs are key elements in order to achieve homogeneous autonomous vehicle fleet. According to Davidson and Spinoulas [21] the traffic flow parameters are getting worse at an early stage, as the too compliant AVs will block the traffic. However, with high AV penetration rate, advanced cruise control, and emerging V2V communication technologies, it is expected that traffic flow is getting more fluid. During scenario modelling consideration of autonomous freight transportation is a missing area; however, the entire urban traffic cannot be modelled without the consideration of the characteristic of them (e.g. loading process).

The major social impacts of AVs in urban area have been described in [22], such as safer roads (fewer accidents), transport time reduction, improvement of energy efficiency and parking benefits. Acceptance and use of AVs is predominantly influenced by their perceived usefulness, effectiveness, ease of use and social influence [23]. When autonomous vehicles take over the road in a large volume, consumer preferences around car-ownership will be transformed, traffic modelling and control will be modified, and moreover hackers will appear [24]. The most important inducements are the safety-related issues. An overwhelming rate of accidents (app. 95\%) is caused by human imperfection. It is estimated that self-driving technology could eliminate $90 \%$ of road traffic accidents [25]. Schoettle and Sivak [26] found that self-driving vehicles were not faulty in any crashes in which they were involved. Furthermore, the overall severity of crash-related injuries has been lower for AVs than for conventional ones.

Through the literature review it has been found that many potential application fields were identified, and there are already promising theoretical correspondences and practical experiences. Nevertheless, all research and development activities should be derived from a system-oriented approach because of the complex and dynamic features of the freight transportation.

\subsection{Concept of Computer Integrated Transportation (CIT)}

The alteration affects not only the transportation itself but the entire supply chain. Introduction of autonomous subsystems has a significant impact on operational management, logistics services, etc. Although AVs operate in the traffic autonomously, their operational management requires advanced computer integrated information systems which are also connected to constituents of the supply chain.

In the Computer Integrated Transportation system, the operational processes (e.g. planning, management, control) are aided by information management functions. These functions are integrated:

- which use common input data groups and/or,

- where the procedures match partially or entirely, as well as,

- which can be performed at the same time and place. 


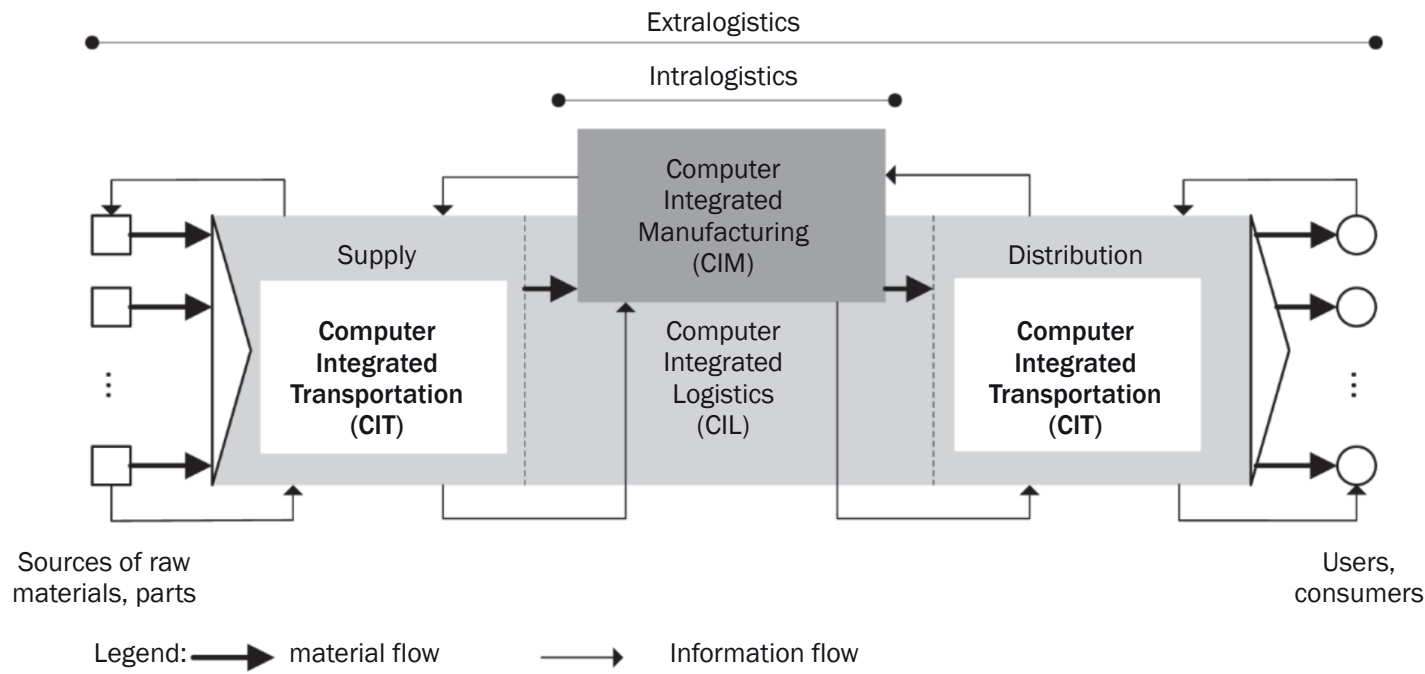

Figure 1 - Connection of computer integrated transportation and manufacturing system

The common database is created according to unified data modelling method. As transportation and logistics systems become more and more complex, effectiveness of operation can be enhanced by methods which consider more and more, increasingly real-time data about processes. The subsystems share data and cooperate to achieve common (global) objectives. All the operational processes are planned, managed and controlled in a coordinated manner. Accordingly, we modelled the entire supply chain revealing the subsystems and their main correspondences (Figure 1).

Flexible manufacturing (production) systems place specific claims towards transportation, because of:

- decrease of manufacturing depth,

- increase of the number of providers (carriers),

- JIT (Just In Time) principle, requiring reliability and flexibility,

- need for special vehicles.

Consequently, computer integrated flexible transportation systems (CIT) based on AVs should be integrated into the computer integrated logistics systems (CIL) which are connected to the computer integrated manufacturing systems (CIM). In the case of services, the notion 'production company' is more appropriate than the notion 'manufacturing company'. The role of warehouses is decreasing and the boundaries of companies are fading. The flexible transportation system can be considered as a 'channel' between the sources of raw materials and parts as well as the consumers using appropriate technological and info-communication background. The supply chain and the needed transportation network should be modelled together as the environmental impacts on supply chain are significant. Therefore, transport networks and supply chain management studies can include analogical methods [27].

\section{SYSTEM STRUCTURE}

During modelling, we applied system engineering principles to envisage the system. Accordingly, both the structure and the operation were mapped. Since alteration of the freight transportation is induced by the vehicle itself, the models were deduced from the properties of AVs.

\subsection{Structural model}

The structural model is summarized in Figure 2. The 'outer' connections, such as social impacts and energy supply, should be always considered during the investigation of 'inner' structure and operation. The main components are on the physical level: autonomous vehicle (AV), cargo, transport infrastructure, energy infrastructure, warehouse, and depot.

The operation is managed and controlled by several types of organisations, such as centres according to the functions:

- transportation management centre: organizes and manages all transportation-related issues, coordinates the other centres,

- infrastructure management centre (A): monitors status, manages facilities, charges for use of infrastructure, facilities and for energy as well as plans, organizes and monitors maintenance,

- fleet management centre (B): organises, monitors, controls and manages the vehicles according to the senders' demand; each freight transport company has a fleet management centre, and

- traffic control centre (C): monitors and controls traffic; manages the effects of incidents and accidents. Cooperation between vehicles and other constituents is inevitable. Novel communication systems are appearing in modern vehicles, which provide V2V 


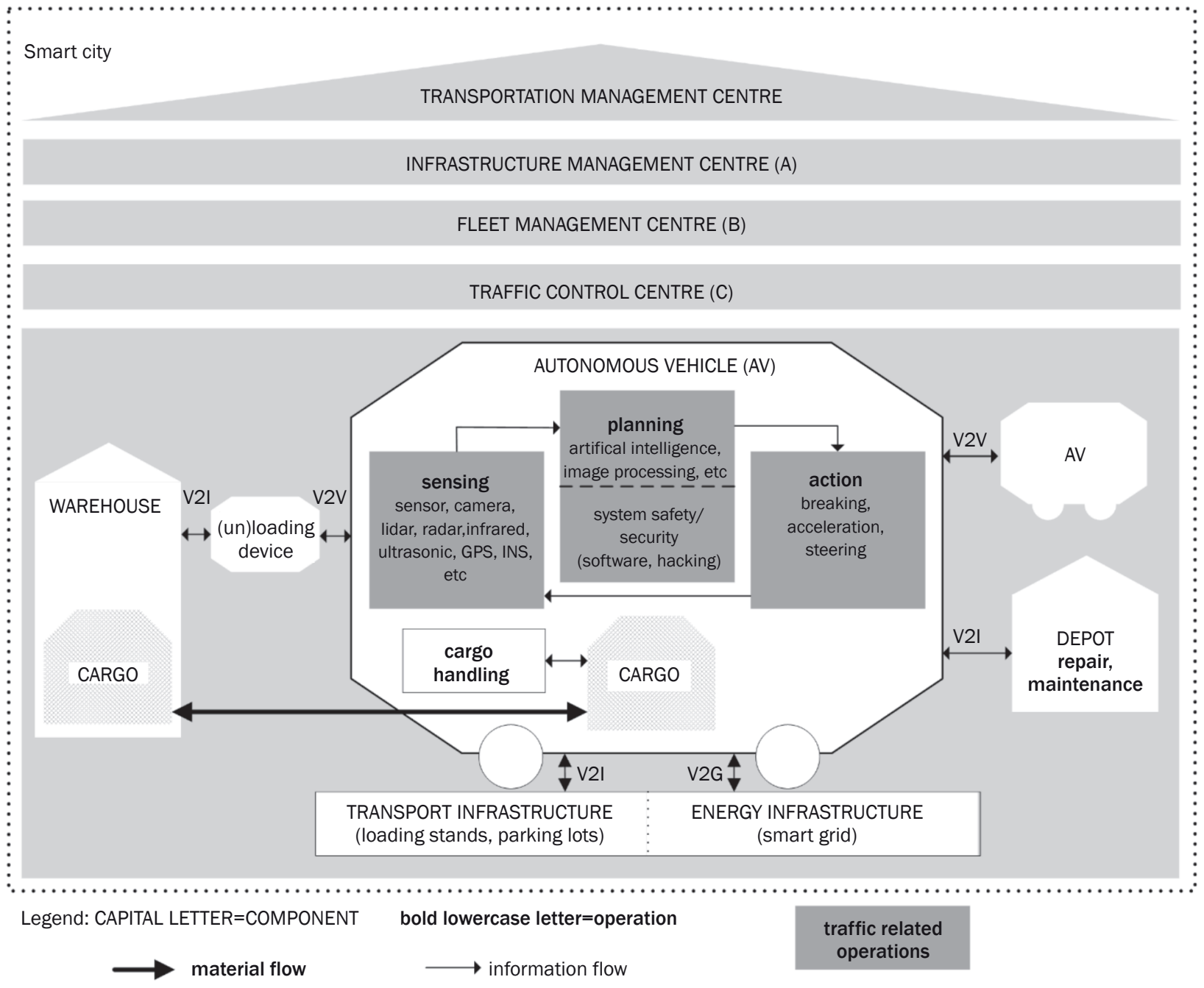

Figure 2 - Structural model

(Vehicle to Vehicle) or V2I (Vehicle to Infrastructure) communication services. The development and standardisation of V2V/V2I technologies are also ongoing processes of our days [28]. Communication should be simulated in order to avoid reducing V2V communication efficiency (e.g. distorted or missing messages, information noise) [29]. V2N (Vehicle to Nomadic device) communication can support the safety and identification functions as well. It transmits GPS-based location and/or heading information about the surrounding moving objects to the other vehicles, passengers or vulnerable road users via smart devices. Therefore, accidents can be avoided using automatic warning in the case of emergency, or the smart devices can be used for user identification.

The basic questions are where to install the 'intelligence' and how to distribute it. The fleet and transportation managers will still be needed even though AVs may control themselves as a subsystem in the traffic. $\mathrm{AVs}$ are managed by the fleet management centre, the infrastructure management centre and the transportation management centre in an integrated manner with consideration of other participants and aiming at global optimal solutions. Functions of the centres may be executed also remotely applying cloud services.

In the case of automated vehicles, most of the 'intelligence' is incorporated in the infrastructure, i.e. the vehicles merely execute the commands of the infrastructure. However, in the case of AVs, the intelligence can be deployed both in the infrastructure and in the vehicle. The current developments design the intelligence mostly into the vehicle in order to prepare the $\mathrm{AV}$ for individual behaviour. However, the economic efficiency of the autonomous system can be significantly improved if the intelligence is distributed between the infrastructure and the vehicle. Highly developed, intelligent infrastructure decreases the production and operation costs of vehicles. Nevertheless, it is feasible only on routes with high operation frequency. The most relevant infrastructure alteration is that the importance of road signs is fading. In addition, management of loading stands and parking lots requires novel procedures. 
The system and vehicles need to be trained to each safety-critical situation as well as automated cargo handling functions (e.g. identification). Loading processes may be performed by human or human aided by devices or by robots. In the latter case, the robot is considered as another AV. The technology should address the safety and security issues, such as security against hacking and terrorist attack as well as thieving. Defending against cyber-attack requires more redundancy that many have been expecting. GNSS spoofing and injection of fake messages were identified as the most dangerous attacks [30]. From legal side, the national and international legislation of AVs should be improved, and the responsibilities should be clarified, especially in the case of accidents.

\subsection{Model of system dynamism}

The new service concepts require novel information management and systems engineering (SE) methodology. Lack of proper procedures is one of the main reasons for failure in information technology (IT) projects. Several different methodologies have been developed over the years to address the SE but they should be improved as the autonomous vehicles are to be integrated in the freight transportation systems. Accordingly, we present the model of system dynamism (Figure 3), which is applicable during data modelling to identify the entities and their attributes. Data map both the static and the dynamic structure which correspond to the planned and the real operation. As the date and time of the delivery task completion is approaching, the data accuracy is increasing because the current status of components is getting known due to monitoring and receiving the senders' real-time announcements.

The most important databases map the components (infrastructure and transport network, AV, smart cargo) and the operation (cargo-vehicle assignment, delivery routes and times, tariff and payment, feedbacks of senders). These data are stored in integrated databases which are primarily managed by the transportation management centre, but the infrastructure management centre, the fleet management centre and the traffic control centre also use these data. Although certain functions are assigned to the centres, their operation is coordinated by the transport management centre and they use the integrated database in common.

\section{OPERATION}

We revealed the most important functions and assigned them to the organisations in order to determine the tasks of the organisations (centres) and the

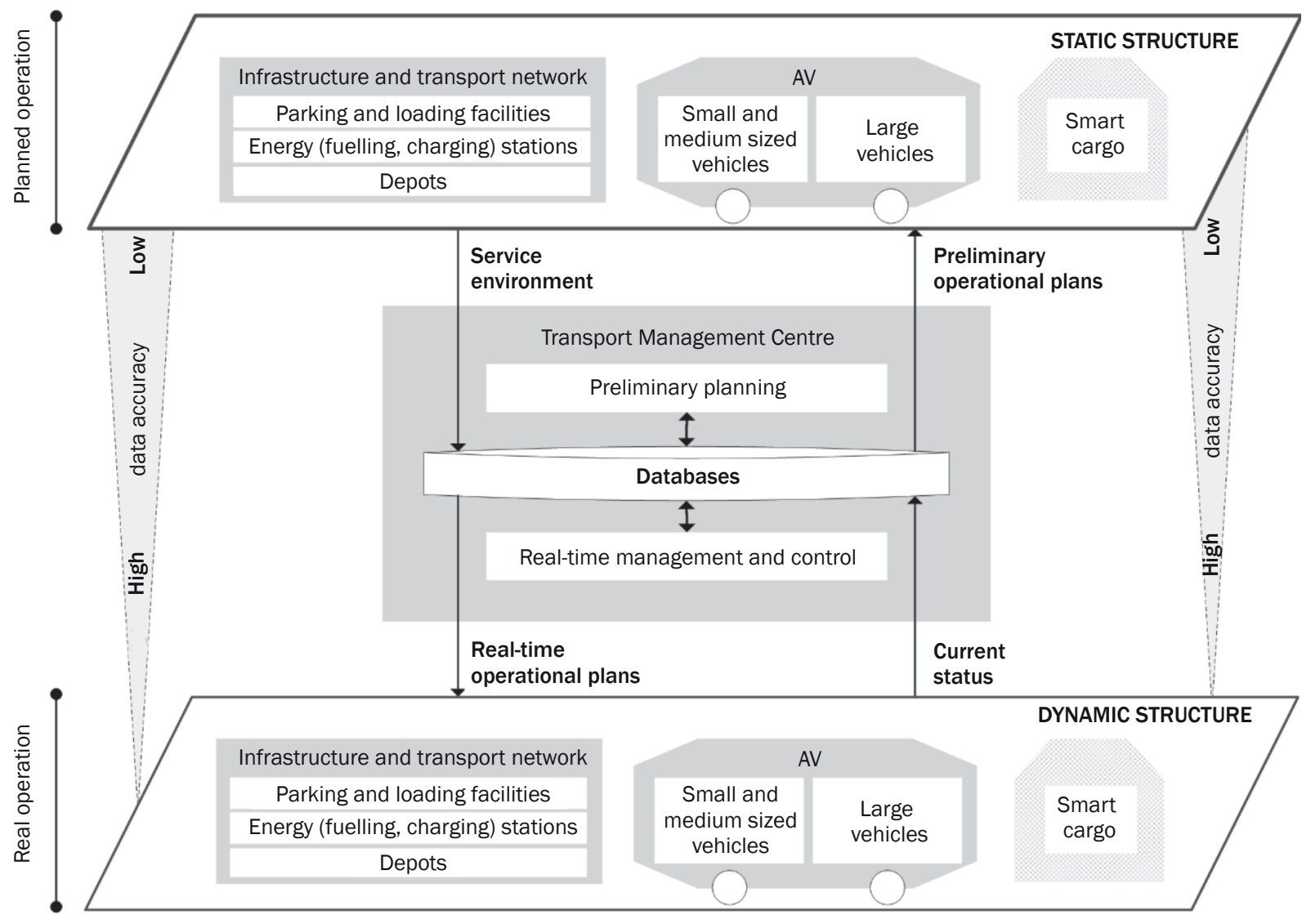

Figure 3 - Model of system dynamism 
cooperation between them. Expectedly, all centres perform more intensive information management. The extension of functions is most relevant in the case of infrastructure management because entirely new functions arise, such as management of loading facility and energy station. The infrastructure itself also alters as conventional parking and resting facilities become energy-charging stations. Management of loading facilities and energy station require booking procedures; otherwise, AVs cannot fulfil the freight task and its schedule fails. The road tolling and infrastructure booking [31] functions belong also to this organisation.

\subsection{Functions}

We identified and classified the functions according to the management centres A-C (Table 1). The function groups are to be assigned to the organisations. We paid special attention to automation of cargo handling function (B8), namely, how the function is to be automated and what consequences are on both the machine and the human side. Loading in warehouses or at customers with significant cargo traffic (e.g. supermarkets) is already solved because picking robots (i.e. indoor automated guided transport) can move cargo automatically. However, private customers perform loading manually, especially in the case of delivery services. They should 'receive' the vehicle and after mutual identification the trunk can be opened and closed/locked.

Since urban public spaces are of high value, management of loading requires novel solutions here. Such combined loading, parking and charging facilities (lots) with timeshare are to be introduced and they should meet the following demands:

- at night, residents' AVs park and recharge,

- in dedicated time intervals, freight AVs serving neighbourhood shops, restaurants, etc. park and recharge during loading,

- in the remaining time intervals, AVs of visitors with different purposes (e.g. office routine, shopping) park and recharge.

These combined facilities (lots) are managed by booking (reservation) procedures applying dynamic rates $\left(A_{2}, A_{3}, A_{4}\right)$. Here, the short-term parking for AVs is also to be introduced. In this manner, the delivery services based on AVs or autonomous taxis can find places for loading/unloading or boarding/alighting purposes. Since success of automated transport processes is highly depending on reliability of parking, modelling and planning as well as real-time management of parking demands is especially important.

Customer relations become increasingly important which cover primarily information provision $\left(B_{7}\right)$ (e.g. general conditions, position of delivery, communication between vehicle and customer) and feedback management $\left(B_{12}\right.$ (e.g. complaining, lost and found).

Table 1 - Information management functions

\begin{tabular}{|c|c|c|}
\hline Group & Sign & Name \\
\hline \multirow{4}{*}{ Infrastructure management } & $A_{1}$ & road network management \\
\hline & $\mathrm{A}_{2}$ & loading facility management \\
\hline & $\mathrm{A}_{3}$ & energy station management \\
\hline & $\mathrm{A}_{4}$ & parking facility management \\
\hline \multirow{6}{*}{ Fleet management - planning/organizing } & $\mathrm{B}_{1}$ & delivery demand analysis and planning \\
\hline & $\mathrm{B}_{2}$ & tariff planning \\
\hline & $\mathrm{B}_{3}$ & (real-time) demand management \\
\hline & $\mathrm{B}_{4}$ & preliminary and operative planning (e.g. vehicle scheduling) \\
\hline & $\mathrm{B}_{5}$ & route (energy recharge) planning \\
\hline & $\mathrm{B}_{6}$ & maintenance planning, repair management \\
\hline \multirow{6}{*}{ Fleet management - control } & $\mathrm{B}_{7}$ & information provision to the customers \\
\hline & $\mathrm{B}_{8}$ & (un)loading management (e.g. cargo/customer identification) \\
\hline & $\mathrm{B}_{9}$ & monitoring (e.g. cargo box conditions) \\
\hline & $\mathrm{B}_{10}$ & safety, security (e.g. cargo protection) \\
\hline & $\mathrm{B}_{11}$ & payment \\
\hline & $\mathrm{B}_{12}$ & feedback management \\
\hline \multirow{2}{*}{ Traffic control } & $\mathrm{C}_{1}$ & vehicle driving control \\
\hline & $\mathrm{C}_{2}$ & traffic (signal) control \\
\hline
\end{tabular}




\subsection{Operational model}

The focus is on operational management and integration potentials of autonomous freight transportation. Accordingly, we elaborated the operational model, where the most relevant connections between the functions are revealed and presented (Figure 4). Most of the functions can be automated partially or entirely, but in the case of certain functions (e.g. $B_{6}, B_{10}, B_{12}$ ) the dispatchers cannot be replaced.

The most relevant or challenging operational issues were summarized focusing on cooperation of organisations and functions. Traffic control is highly interrelated with infrastructure management because moving and stationary traffic is better coordinated than before; namely, AVs should be controlled seamlessly. Integration of traffic control and fleet management is also resulting in more efficient operation as the route is planned with considerations to the real-time traffic situations. According to the characteristics of cargo, disparate vehicle control strategies are to be applied.
For instance, different acceleration and deceleration parameters are permitted with consideration of the cargo fragility and the way of fixation. This kind of 'soft' control is not possible in the case of driver. Since the number of traffic incidents decreases, re-planning of routes or entire freight tasks are less often needed. The entire transportation becomes more predictable and reliable; however, the environmental effects and the remaining human participants may influence these well-organized processes, too.

In the integrated system, multi-level optimisation tasks are to be solved considering the real-time data and economical aspects. In most cases, the management of capacities (e.g. road network, loading and parking facilities, energy stations) is to be coordinated with consideration of the current demands. As a global optimum criterion, the minimisation of energy consumption is to be achieved. Beside the information, the dynamic prices can be applied as efficient tool for demand influence.

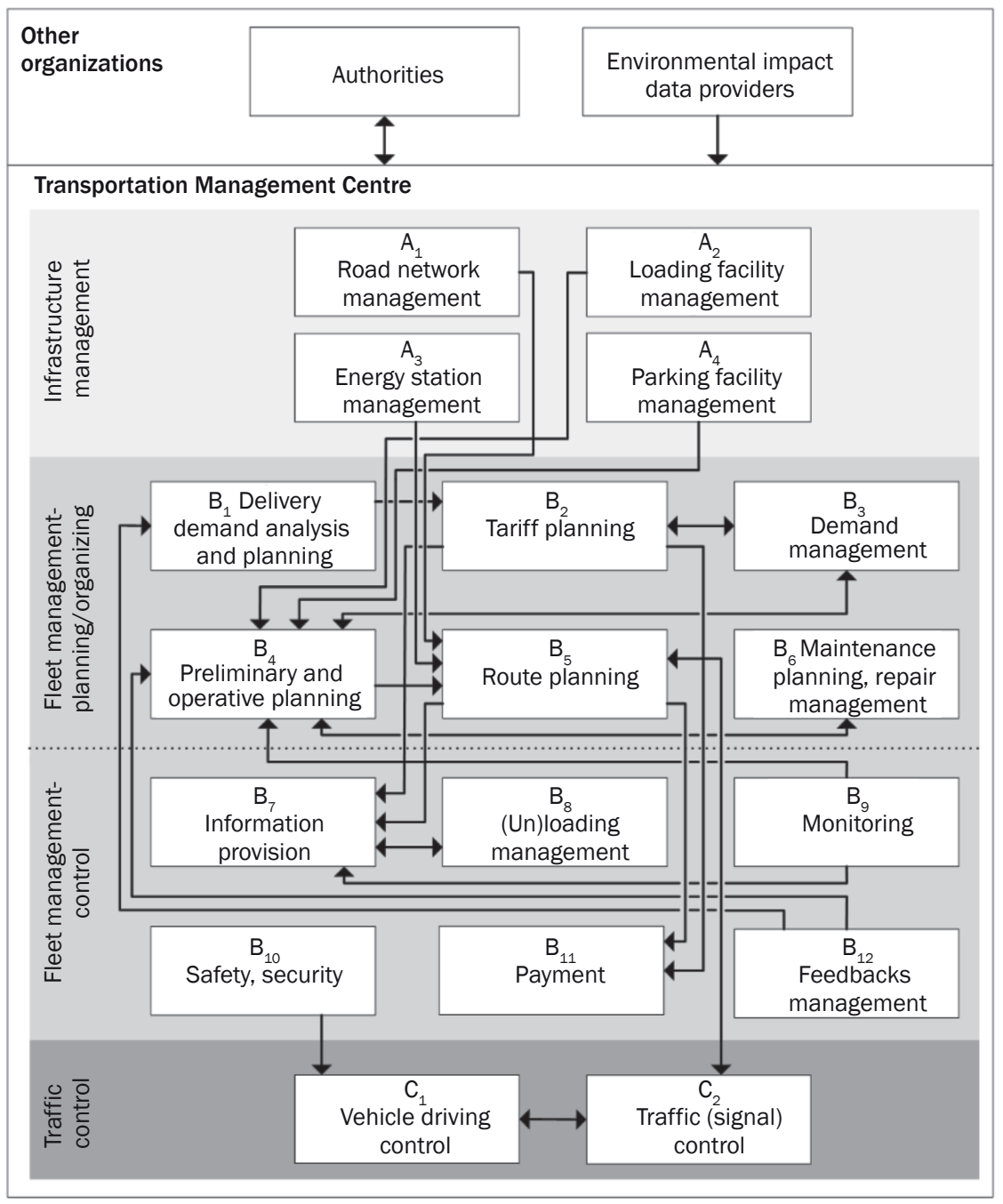

Legend: $\longrightarrow$ Information flow

Figure 4 - Operational model 


\section{CONCLUSIONS}

Planning and operation of future freight transportation will be much more complex than before. Therefore, new analysis and modelling methods should be elaborated and applied in order to facilitate the creation of new services. As the technological background is (will be) available, this tendency addresses enormous challenges towards system researchers, engineers and operators.

Among the main contributions of the paper we highlight the structural model and the operational model. Our results may have high relevance for innovation and development. Key findings include the following:

- road transport system becomes highly supported by information systems; most of the constituents manage information,

- integrated systems and coordinated procedures are needed to exploit the obvious potentials of AVs and automation of supply chains.

The most relevant advantages of road freight transportation based on AVs are:

- operation time of vehicles can be significantly increased; therefore, fewer vehicles are needed,

- fewer accidents, less damage of cargo.

The composition of vehicle stock may alter according to the size and transport distance. In some cases, the transhipment and logistics centres in suburbs of metropolitan areas are not needed any more as urban delivery vehicles can be sent for regional or long-distance transportation tasks directly. In this case, the capacity utilisation of road infrastructure may be enhanced by platooning. Nevertheless, the trucks and containers require transhipment and logistics centres in the future, too.

As the integration of information systems is an enormous and complex task, not only intuitively but also physically, future research is expected to proceed in several directions. Our future plans include:

- Modelling of an entire autonomous transport system (passenger and freight as well), with special regard to urban context, in order to reveal quantitative correspondences: we are going to prepare forecasting models regarding citizens' mobility demands, number and types of AVs and required infrastructure capacities (road, loading, parking and charging facilities).

- Elaboration of a method for coordination of freight transport tasks and capacities: we are going to elaborate a complex operational method and algorithm which consider (real-time) attributes and status of both delivery tasks and vehicles. The coordination is performed according to several conditions and requirements towards energy and cost efficiency.
- Assessment of socioeconomic benefits: we are going to reveal both the direct economic benefits (e.g. reduction in delivery prices) and the benefits realized at customers (e.g. reliable last-mile service) in a quantitative manner. We compare the main indicators of current systems and services with the envisaged attributes of the system.

\section{ACKNOWLEDGEMENT}

Supported by the ÚNKP-17-3-I New National Excellence Program of the Ministry of Human Capacities

Dr. CSISZÁR CSABA, Ph.D., egyetemi docens ${ }^{1}$

E-mail: csiszar.csaba@mail.bme.hu

FÖLDES DÁVID, Ph.D. hallgató ${ }^{1}$

E-mail: foldes.david@mail.bme.hu

${ }^{1}$ Budapesti Múszaki és Gazdaságtudományi Egyetem (BME), Közlekedésmérnöki és Jármúmérnöki Kar (KJK), Közlekedésüzemi és Közlekedésgazdasági Tanszék (KUKG) ,1111. Budapest, Múegyetem rkp.3. Magyarország

\section{AUTONÓM KÖZÚTI ÁRUSZÁLLITÁS RENDSZERMODELLJE}

\section{ABSZTRAKT}

A fejlődő infokommunikációs és jármütechnológia (különösképpen a jármúvek automatizálása) elôsegíti az autonóm közúti áruszállitás kialakulását. A teljes közlekedési rendszer és müködése jelentősen átalakul. Új szolgáltatási koncepciók jelennek meg és a meglévök átalakulnak. A változás a városi logisztikában különösen jelentôs. A kapacitáskihasználás javítását és a ráfordítások csökkentését célzó folyamatok automatizálási módjáról azonban eltérô nézópontok vannak. Ennek következtében a kutatási alapkérdések: várhatóan milyen tulajdonságokkal rendelkezik az autonóm közúti áruszállítás; milyen rendszert érdemes létrehozni és azt hogyan múködtessük? Az alapfogalmak definiálása, a jelenlegi rendszerek és fejlesztésekáttekintése után, a hagyományos áruszállítás autonóm rendszerré válását vizsgáltuk számos szempont szerint. Feltártuk a fô rendszerösszetevőket és kapcsolataikat rendszer- és folyamatszemléletú analitikus modellezési módszert alkalmazva. Végezetül, kidolgoztuk az autonóm közúti áruszállítás üzemeltetési modelljét elsősorban nagyvárosi környezetre. A bemutatott eredmények meghatározzák a kutatási és innovációs irányokat az áruszállítási automatizáció területén.

\section{KULCSSZAVAK}

autonóm áruszállító jármü; rendszer struktúra; üzemeltetési modell; városi logisztika;

\section{REFERENCES}

[1] Flämig $\mathrm{H}$. Autonomous Vehicles and Autonomous Driving in Freight Transport. In: Maurer M, Gerdes JC, Lenz B, Winnerpp $\mathrm{H}$, editors. Autonomous Driving. Berlin, Heidelberg: Springer; 2016. p. 365-385. doi: 10.1007/978-3-662-48847-8

[2] Alessandrini A, Campagna A, Site PD, Filippi F, Persia L. Automated Vehicles and the Rethinking of Mobility and Cities. Transportation Research Procedia. 2015;5: 
145-160. doi: 10.1016/j.trpro.2015.01.002

[3] Wilson B. Systems, concepts, methodologies, and applications. New York: Wiley; 1984.

[4] NHTSA, National Highway Traffic Safety Administration. U.S. Department of Transportation Releases Policy on Automated Vehicle Development; 2013. Available from: www.nhtsa.gov

[5] McFarlane D, Sarma S, Chirn JL, Wong CY, Ashton $\mathrm{K}$. Auto ID systems and intelligent manufacturing control. Engineering Applications of Artificial Intelligence. 2003;16(4): 365-76. doi: 10.1016/S09521976(03)00077-0

[6] Arango Serna MD, Serna Uran CA, Alvarez Uribe KC. Collaborative autonomous systems in models of urban logistics. Dyna (Medellin, Colombia). 2012;79(172): 171-179.

[7] Lom M, Pribyl O, Svitek M. Industry 4.0 as a Part of Smart Cities. Proceedings of the SCSP 2016, Smart City Symposium 2016; 2016 May 26-27; Prague, Czech Republic; 2016. doi: 10.1109/SCSP.2016.7501015

[8] SAE International. Taxonomy and Definitions for Terms Related to On-Road Motor Vehicle Automated Driving Systems; 2014. Available from: http://standards.sae. org/j3016_201401

[9] Gasser TM, Arzt C, Ayoubi M, Bartels A, Bürkle L, Eier J, Flemisch F, Hacker D, Hesse T, Huber W, Lotz C, Maurer M, Ruth-Schumancher S, Schwarz J, Vogt W. Legal consequences of an increase in vehicle automation. Consolidated final report of the project group, Part 1. Bergisch Gladbach: Bundesanstalt für Straßenwesen (Germany); 2012. Available from: http://bast.opus. hbz-nrw.de

[10] UITP (Union International des Transport Public), International Association of Public Transport. Press Kit Metros automation facts, figures and trends; 2011. Available from: http://www.uitp.org/metro-automation-facts-figures-and-trends

[11] Corman F, Xin J, Negenborn RR, D'Ariano A, Samà M, Toli A. Optimal Scheduling and Routing of Free-range AGVs at Large Scale Automated Container Terminals. Periodica Polytechnica Transportation Engineering. 2016;44(3): 145-54. doi: 10.3311/PPtr.8620

[12] Kückelhaus, M. Self-driving vehicles in logistics: A DHL perspective on implications and use cases for the logistics industry. Troisdorf, Germany: DHL Trend Research; 2014. Available from: https://www.dhl.de/content/ dam/dhlde/images/ueber_uns/content/dhl_self-driving_vehicles.pdf [Accessed $13^{\text {th }}$ March 2017]

[13] Sternberg H, Andersson M. Decentralized intelligence in freight transport - A critical review. Computers in Industry. 2014;65(2): 306-13. doi: 10.1016/j.compind.2013.11.011

[14] Arendt F, Klein O, Barwig K. Intelligent Control of Freight Services on the Basis of Autonomous Multiagent Transport Coordination. In: Zijm H, Klumpp M, Clausen U, Hompel MT, editors. Logistics and Supply Chain Innovation. Springer International Publishing; 2016. p. 313-324.

[15] Gao S, Lim A, Bevly D. An empirical study of DSRC V2V performance in truck platooning scenarios. Digital Communications and Networks. 2016;2(4): 233-244. doi: 10.1016/j.dcan.2016.10.003

[16] van Arem B, van Oort N, Yap M, Wiegmans B, Homem de Almeida Correia G. Opportunities and challenges for automated vehicles in the Zuidvleugel. Delft University of Technology; 2015. p. 36. Available from: https:// nielsvanoort.weblog.tudelft.nl/files/2015/03/ TUD2103-essay-final.pdf [Accessed $13^{\text {th }}$ March 2017]

[17] Pereira A M, Anany H, Pribyl O, Prikryl J. Automated Vehicles in Smart Urban Environment: A Review. Proceedings of the SCSP 2017, Smart City Symposium 2017; 2017 May 25-26; Prague, Czech Republic; 2017. doi: 10.1109/SCSP.2017.7973864

[18] Milakis D, Snelder M, van Arem B, van Wee GP, Homem de Almeida Correia G. Development of automated vehicles in the Netherlands: scenarios for 2030 and 2050. European Journal of Transport and Infrastructure Research. 2017;17(1): 63-85.

[19] Gruel W, Stanford JM. Assessing the long-term effects of autonomous vehicles: a speculative approach. Transportation Research Procedia. 2016;13: 18-29. doi: 10.1016/j.trpro.2016.05.003

[20] Bansal P, Kockelman KM. Forecasting Americans' long-term adoption of connected and autonomous vehicle technologies. Transportation Research Part A: Policy and Practice. 2017;95: 49-63. doi: 10.1016/j. tra.2016.10.013

[21] Davidson P, Spinoulas A. Autonomous Vehicles: What Could This Mean for the Future of Transport? Proceedings of the Australian Institute of Traffic Planning and Management (AITPM) National Conference, Brisbane, Australia; 2015.

[22] Fagnant DJ, Kockelman KM. Preparing a nation for autonomous vehicles: opportunities, barriers and policy recommendations. Transportation Research Part A: Policy and Practice. 2015;77: 167-181. doi: 10.1016/j.tra.2015.04.003A.

[23] Nordhoff S, van Arem B, Happee R. Conceptual Model to Explain, Predict, and Improve User Acceptance of Driverless Podlike Vehicles. Transportation Research Record: Journal of the Transportation Research Board. 2016;2602: 60-67. doi: 10.3141/2602-08

[24] Tettamanti T, Varga I, Szalay Z. Impacts of Autonomous Cars from a Traffic Engineering Perspective. Periodica Polytechnica Transportation Engineering. 2016;44(4): 244-250. doi: 10.3311/PPtr.9464

[25] Waldrop MM. Autonomous vehicles: no drivers required. Nature. 2015;518(7537): 20-23. doi: 10.1038/518020a

[26] Schoettle B, Sivak M. A preliminary analysis of real-world crashes involving self-driving vehicles. Transportation Research Institute, University of Michigan. Report No. UMTRI-2015-34, 2015.

[27] Dömötörfi Á, Péter T, Szabó K. Mathematical Modeling of Automotive Supply Chain Networks. Periodica Polytechnica Transportation Engineering. 2016;44(3): 181-186. doi: 10.3311/PPtr.9544

[28] Maurer M, Winner H. Automotive systems engineering. Springer; 2013.

[29] Gora P, Rüb I. Traffic models for self-driving connected cars. Transportation Research Procedia. 2016;14: 2207-2216. doi: 10.1016/j.trpro.2016.05.236

[30] Petit J, Shladover SE. Potential Cyberattacks on Automated Vehicles. IEEE Transactions on Intelligent Transportation Systems. 2015;16(2): 546-556. doi: 10.1109/TITS.2014.2342271

[31] Soltész T, Kózel M, Csiszár C, Centgráf T, Benyó B. Information System for Road Infrastructure Booking. Periodica Polytechnica Transportation Engineering. 2011;39(2): 55-62. doi: 10.3311/pp.tr.2011-2.02 